February 5, 2020

\title{
Rising Student Debt and the 2020 Election
}

James Kvaal and Jessica Thompson

\section{Introduction}

In the 2020 presidential election campaign, college affordability has become a central household economic issue that nearly every candidate feels compelled to address.

Students and their families understand that an education beyond high school-whether a job training certificate, a community college degree, a four-year university diploma, or a graduate degreeis more critical to their future than ever. Employers know that educated workers are key to productivity. Most policymakers understand that increased educational attainment is essential to continued economic growth and shared prosperity.

However, despite college's growing importance, there has been a widening gulf over the last several decades between college costs and students' ability to pay them, and as a result American families have faced a rising tide of student debt. State funding for public colleges and universities has steadily declined, contributing to higher tuitions for most students. Federal student debt outstanding now totals $\$ 1.5$ trillion, up from $\$ 577$ billion in 2008. ${ }^{1}$ While education loans help many earn college degrees, many others are left worse off for having attended college. More than a million former students default on their loans each year.

From eliminating college tuition to canceling student debt, many of the men and women who seek to lead the country have proposed ambitious investments in college affordability. If enacted, these proposals would represent an unprecedented federal commitment to college. Nearly all of the candidates propose hundreds of billions if not trillions of dollars in new spending. This perspectives brief explores the challenge of college affordability and summarizes the campaign proposals to address it.

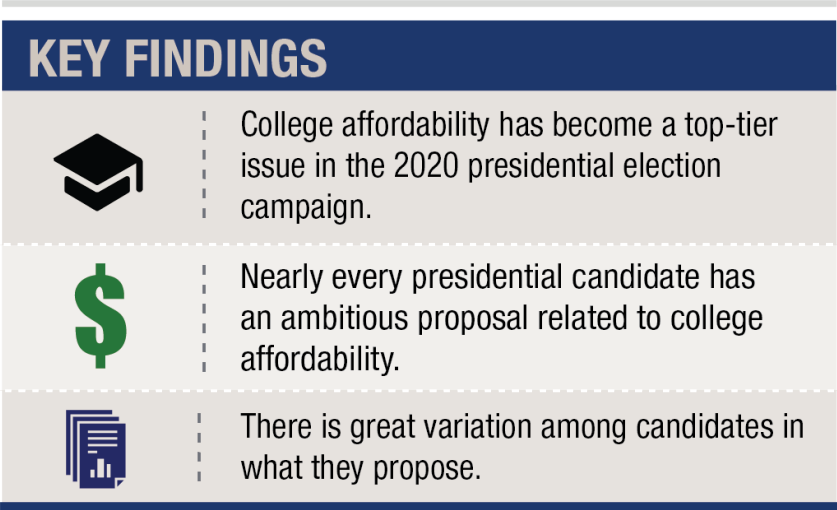

\section{College Costs in 2020: Affordability Gaps and Rising Debts}

\section{The Growing Importance of College}

Both the likelihood of employment and actual earnings increase with higher levels of education. The unemployment rate among Americans with at least a bachelor's degree is less than one-half the rate for those with only a high school diploma, ${ }^{2}$ and the wage premium - the extra earnings received-for a four-year college graduate is more than $\$ 30,000$ per year, near an all-time high. ${ }^{3}$ Community college graduates also enjoy higher earnings than high school graduates. ${ }^{4}$

College can also be a powerful force for promoting equity in economic opportunity. Students from both low- and high-income families who attend the same college earn similar incomes in adulthood. ${ }^{5}$ The returns of college are equally high for additional students who are drawn into school by additional support. ${ }^{6}$

The benefits of postsecondary education extend beyond the individual students themselves. Education fuels greater innovation and productivity, increased tax revenue, reduced criminal behavior, improved health, and higher civic participation rates. ${ }^{7}$ 


\section{State Budget Cuts Contribute to Growing College Costs}

Students who have made it to college over the past several decades have faced steadily rising costs. In the distant past, students might have reasonably expected to pay their tuition and living expenses with the earnings from a part-time or summer job. But for decades now, college costs have risen inexorably, and increasing costs without equal increases in grant aid have resulted in pervasive affordability challenges and rising student debt.

A key driver of increased costs for students is the steady decline in state funding for public colleges and universities, which enroll three-quarters of all students. ${ }^{8}$ States often make deep cuts in higher education during economic downturns, but they tend not to replace the funds when times are good. This trend accelerated during the Great Recession, when almost all states made deep cuts. More than a decade later, average state support per student remains 13 percent $(\$ 1,220$ per student) below what it was before the Great Recession. ${ }^{9}$

State funding is not only declining but it is also distributed inequitably. ${ }^{10}$ Underrepresented students of color disproportionately attend public colleges and universities that have less money to support them and where graduation rates are low. Community colleges serve the highest shares of underrepresented students of color and have just a fraction of the state support and tuition revenue available to other colleges in the same state. ${ }^{11}$

To cover rising costs, students have taken on debt. As costs have increased and more low-income students have enrolled in public colleges, the share of bachelor's degree recipients with federal and private student loan debt increased from 62 percent to 69 percent between 2000 and 2016. Four-year college graduates are also borrowing more: the average debt load increased 23 percent between 2000 and 2016, after inflation. ${ }^{12}$

There was particularly steep growth in student debt at public colleges during the Great Recession. Between 2008 and 2012, state and local appropriations per student fell by over $\$ 2,000$, and average annual federal loan borrowing (including students who did not borrow) rose by nearly $\$ 1,100$ per student. ${ }^{13}$

\section{College Costs Are a Barrier to Enrollment and Completion}

College costs include not only tuition and fees but also living expenses, textbooks, transportation, and other expenses. Even after scholarships, the remaining costs-the amount students must contribute from savings or earnings or from borrowing - can be very high. The maximum Pell grant-the federal college scholarship that helps low-income students pay tuition and living expenses-today covers only 28 percent of college costs, the lowest share in over 40 years. This decline is particularly problematic for underrepresented students of color given that more than half of them come from families earning less than $\$ 30,000$ a year. ${ }^{14}$ To pay for college at today's prices without loans, these students would have to rely on half their families' total income to cover the cost of attending a community college, even after receiving grant aid. An average public university would take 77 percent of their families' income. ${ }^{15}$

Low-income college students share the complex realities of other low-income Americans, such as the need to support children or other family members, unstable low-wage jobs, and unexpected expenses like car repairs. ${ }^{16}$ The current financial aid system is not only underfunded but is not designed to help students meet extra needs or absorb unexpected financial blows.

Students cope with affordability gaps in different ways. Some choose not to enroll at all. Others work long hours, reducing the time available for their studies and their likelihood of completion. ${ }^{17} \mathrm{~A}$ long line of research shows that each $\$ 1,000$ reduction in cost increases enrollment by three to five percentage points. ${ }^{18}$ Working more than 15 hours per week comes at the expense of academic success for lowerincome students. ${ }^{19}$

As a result, while degree attainment has increased across the board, large equity gaps persist. Young people with high-earning parents are five times more likely to earn college degrees by age 24 than their low-income peers. ${ }^{20}$ While 34 percent of American adults have a bachelor's degree or higher, only 24 percent of black adults and 17 percent of Latino adults do. ${ }^{21}$ 


\section{A Concentrated Crisis in Student Debt}

Federal student loans help millions of students enroll in college and complete their degrees when they otherwise could not afford to do so. The returns to most college degrees are high, and most students successfully repay their loans. ${ }^{22}$

However, student debt can be burdensome. While the economic benefits of college often accrue over time, loan payments begin six months after the student leaves school. Research shows that student debt can reduce rates of homeownership, affect career choices, and even delay decisions to start a family. ${ }^{23}$ Like all research, these studies necessarily look in the rearview mirror. The impact of student debt on students attending during and shortly after the Great Recession, who have borrowed at higher levels, is not yet fully understood.

Moreover, there is a concentrated crisis among the more than one million students who default each year and suffer consequences that can drive them deeper into debt and, ironically, make it harder for them to repay their loans. ${ }^{24}$ Upon entering default, the entire unpaid balance, including accumulated interest, becomes due. To collect unpaid debt, the federal government can garnish a defaulted borrower's wages, as well as withhold tax refunds and other federal benefit payments.

Black graduates are specifically more likely to borrow and to borrow more than students of other races. Over eight in ten black bachelor's degree recipients graduated with an average of $\$ 34,000$ in debt in 2016, higher than the averages for white, Latino, and Asian graduates. ${ }^{25}$ One economist projects that as many as 70 percent of black borrowers may eventually default, a shocking finding that underscores the urgent need to address racial inequities in college financing. ${ }^{26}$

Low-income students are also more likely to borrow, to borrow more, and to default than their peers. ${ }^{27}$ Older borrowers, students who attend part time and attend nonselective schools, and students who leave school without a certificate or degree are also more likely to default, even though they often have comparatively small initial loan balances. ${ }^{28}$
Default is highly concentrated at certain colleges. For-profit colleges enroll only 9 percent of all students, yet 33 percent of the borrowers who defaulted within three years of leaving school attended for-profit colleges. ${ }^{29}$ In recent years, government investigations have found extensive illegal behavior at some forprofit colleges, including the collapsed national chains Corinthian Colleges and ITT Tech. The combination of high-pressure, deceptive recruiting tactics and lowquality education has left many students with large debts they are unable to repay. ${ }^{30}$

\section{The 2020 Election: Ambitious New Ideas for College Affordability}

Almost all of the candidates for president have proposed major reforms to address college costs and student debt, and many of the plans would cost hundreds of billions of dollars over the next decade. However, the diversity of approaches is striking. Most candidates pledge to eliminate tuition at some colleges for some students, but there is substantial variation in scope. Similarly, most candidates would reduce payments on existing loans, but some provide greater relief to students with the largest debts (who may also have greater means to repay those debts) while others target relief to economically vulnerable borrowers or those in public service.

\section{Free College Proposals}

All of the Democratic candidates support some form of free college. Senator Michael Bennet, Vice President Joe Biden, Sen. Amy Klobuchar, Gov. Deval Patrick, and Mr. Tom Steyer would provide money to states to eliminate tuition at community colleges. ${ }^{31}$ These programs would be jointly funded by the federal government and states.

Mr. Andrew Yang would make community college "tuition free or nearly free," funded by the government and businesses. ${ }^{32}$ Among Republicans, Gov. Bill Weld would offer two free years at a community college or a university and train displaced workers for newly created jobs. ${ }^{33}$ 
Some candidates would make not only community colleges but also public universities free for low- and middle-income families. Mayor Pete Buttigieg would eliminate tuition at all public colleges and universities for students with family incomes under $\$ 100,000$ and offer at least some subsidies for those earning under $\$ 125,000 .{ }^{34}$ Other candidates go further. Sen. Elizabeth Warren would make all public colleges and universities tuition-free. ${ }^{35}$ Sen. Bernie Sanders and Rep. Tulsi Gabbard would eliminate tuition at public schools as well as private historically black and other minority-serving colleges. ${ }^{36}$

\section{Pell Grants and Financial Aid}

Nearly all of the Democratic candidates would also increase spending on Pell Grants, which help lowincome students pay tuition and living expenses at all colleges and universities. Vice President Biden and Sen. Klobuchar would double the size of Pell Grants (now about \$6,200); Sen. Klobuchar would also expand eligibility to families earning up to $\$ 100,000 .{ }^{37}$ Mayor Buttigieg and Sen. Warren would invest smaller amounts to increase Pell grants by about $\$ 1,000$ per student. ${ }^{38}$ Sen. Sanders would also triple the number of work-study jobs. ${ }^{39}$

Sen. Bennet supports expanding Pell Grants to technical training. ${ }^{40}$ President Trump would extend Pell Grants to programs that are shorter than the traditional academic semester. ${ }^{41}$

\section{Student Loan Cancellation}

Many candidates have proposed forgiving at least some student debt. Sen. Sanders would write off $\$ 1.6$ trillion in student loans. ${ }^{42}$ Sen. Warren has proposed forgiving the first $\$ 50,000$ in debt, based upon income, and promised to do so on day one of her presidency. ${ }^{43}$

Sen. Bennet, Vice President Biden, and Gov. Weld would provide additional loan forgiveness to those in public service ${ }^{44} \mathrm{Mr}$. Steyer would improve the implementation of the public service loan forgiveness promised by current law. ${ }^{45} \mathrm{Sen}$. Klobuchar would forgive loans for those in in-demand occupations. ${ }^{46}$

Rep. Gabbard and Mr. Yang would allow loans to be discharged in bankruptcy. ${ }^{47}$ According to the Wall Street Journal, President Trump is also considering this step. ${ }^{48}$
Mayor Buttigieg and Gov. Patrick would cancel debt for borrowers who attended low-quality forprofit colleges. ${ }^{49} \mathrm{Mr}$. Yang promises to "explore a blanket partial reduction in the principal of school loans" and to ask colleges to forgive the loans of students who do not graduate. ${ }^{50}$

\section{Student Loan Repayment}

Several candidates have proposed changing the terms of income-driven repayment, which allows students to repay their loans as a share of income. Most students in income-driven repayment pay 10 percent of their income, above a living allowance, for 20 years or until the loan is paid off, whichever happens first.

President Trump proposes to set payments at 12.5 percent of income over 15 years (30 years for graduate students), increasing payments for some borrowers while reducing them for others. His plan would reduce government costs by a net of approximately $\$ 13$ billion a year. ${ }^{51}$

Several candidates would reduce payments under income-driven repayment for all borrowers. Sen. Bennet would cut monthly loan payments to 8 percent of income. ${ }^{52}$ Vice President Biden proposes 5 percent. ${ }^{53} \mathrm{Mr}$. Yang proposes 10 percent of income for 10 years, combined with a partial reduction in loan principal. $^{54}$

\section{Student Loan Interest Rates}

Sen. Sanders and Rep. Gabbard would set interest rates on future loans at 1.9 percent, roughly half current rates. ${ }^{55}$ Rep. Gabbard, Sen. Klobuchar, Gov. Patrick, and Mr. Steyer would allow existing loans to be refinanced at lower rates. ${ }^{56}$ President Trump is reported to be considering similar proposals. ${ }^{57}$ Gov. Weld would allow loans to be refinanced, reduce interest accumulation, and expand public service loan forgiveness. ${ }^{58}$

\section{Student Outcomes}

Vice President Biden, Mayor Buttigieg, and Sen. Klobuchar propose stricter accountability standards for for-profit colleges. ${ }^{59}$ Sen. Warren would eliminate federal funding for for-profit colleges. Sen. Bennet and Mr. Yang propose publishing data on employment outcomes and applying default rate or 
debt-to-income standards to all colleges receiving federal student aid. ${ }^{60}$ To help students make informed choices, under President Trump the Department of Education has published additional data on student earnings on the College Scorecard website.

\section{Historically Black Colleges}

As described above, some candidates include historically black colleges and universities in their free tuition plans. Mayor Buttigieg would also invest $\$ 50$ billion in historically black colleges ${ }^{61}$ Vice President Biden $\$ 70$ billion. ${ }^{62}$ Gov. Patrick would "seed the endowments" of these schools, ${ }^{63}$ while Sen. Sanders would invest $\$ 1.3$ billion a year in private historically black colleges (in addition to making them tuition-free). ${ }^{64}$

\section{Conclusion}

Driven by steadily rising college costs and student debt, the 2020 presidential campaign has put the issues of college costs and student debt on the agenda as never before. Many candidates are promising to transform the federal investment in college affordability, but there is great variety in how they would structure their initiatives. The debate on the strengths and weaknesses of these plans on the campaign trail is likely to have a substantial influence on future higher education policy. 


\section{Endnotes}

1. Federal Student Aid, U.S. Department of Education, 2019. Federal Student Loan Portfolio Summary, https://bit. ly/2uR3cqO.

2. National Center for Education Statistics, U.S. Department of Education, 2018, https://bit.ly/2vrsNXL. Rates refer to all those workers ages 25 to 64 in 2018.

3. Liberty Street Economics, 2019, "Despite Rising Costs, College Is Still a Good Investment," https://nyfed. org/2S6P2Kn.

4. National Center for Education Statistics 2018.

5. "Mobility Report Cards: The Role of Colleges in Intergenerational Mobility," 2017, Raj Chetty, John Friedman, Emmanuel Saez, Nicholas Turner, and Danny Yagan, https://bit.ly/2k1cnKG.

6. "Making College Worth It: A Review of the Returns to Higher Education," 2013, Philip Oreopoulos and Uros Petronijevic, https://bit.ly/38Z61ES; "The Returns to Higher Education for Marginal Students: Evidence From Colorado Welfare Recipients," 2015, Lesley J. Turner https://bit. ly/2uC4mq2.

7. "Investing in Higher Education: Benefits, Challenges and the State of Student Debt," 2016, White House Council of Economic Advisers, https://bit.ly/2Uu2jfX.

8. Calculations by TICAS on data from the U.S. Department of Education's Integrated Postsecondary Education Data System for 12-month enrollment for all students enrolled in 2016-2017 in schools in the 50 states and the District of Columbia. Figures include both two-year and four-year public institutions and both undergraduate and graduate students.

9. Center on Budget and Policy Priorities, 2019, "State Higher Education Funding Cuts Have Pushed Costs to Students, Worsened Inequality," https://bit.ly/2RWxRe3.

10. TICAS, 2019, "Dire Disparities: Patterns of Racially Inequitable Funding and Student Success in Public Postsecondary Education," https://bit.ly/2Zn7TXL.

11. TICAS, 2019. Underrepresented students include Black, Hispanic, Native Hawaiian or Pacific Islander, and American Indian and Alaskan Native students.

12. Calculation by TICAS on data from the National Postsecondary Student Aid Study 2015-16. For more on how debt varies among students graduating from a fouryear college, see TICAS, "Quick Facts About Student Debt," https://bit.ly/36YgL4Z.

13. TICAS, 2019, "Student Debt and the Class of 2018," https://bit.ly/37xpmwH.

14. Calculations by TICAS on data from the National Postsecondary Student Aid Study, 2015-16.
Underrepresented students of color include students who identify as Black, Hispanic, Native Hawaiian or Pacific Islander, and American Indian and Alaskan Native students.

15. TICAS, 2017 "College Costs in Context: A State-By-State Look at College (Un)Affordability," https://bit.ly/2krAm7K.

16. TICAS, 2019, "The Road Less Fragile: First Steps for Helping Financially Vulnerable Students Succeed,", https:// bit.ly/2UxnFZK.

17. White House Council of Economic Advisers, 2016.

18. See, for example, David S. Mundel, "What Do We Know About the Impact of Grants to College Students?" in Sandy Baum and Michael McPherson, eds., The Effectiveness of Student Aid Policies: What the Research Tells Us, College Board, 2008, https://bit.ly/2J4zzJq; Susan Dynarski and Judith Scott-Clayton, "Financial Aid Policy: Lessons From Research," National Bureau of Economic Research Working Paper No. 18710, January 2013, https://bit.ly/2Tu1mYB.

19. "Balancing Work and Learning: Implications for LowIncome Students," Georgetown University Center on Education and the Workforce, 2018, Anthony P. Carnevale and Nicole Smith, https://bit.ly/2NMJQaP.

20. Pell Institute, 2018, "2018 Indicators of Higher Education Equity in the United States," https://bit.ly/2yVlHd0. "Highearning" refers to the highest family income quartile; "lowincome" refers to the lowest family income quartile.

21. National Center for Education Statistics, U.S. Department of Education, 2018, "Digest of Education Statistics," Table 104.10: "Rates of High School Completion and Bachelor's Degree Attainment Among Persons Age 25 and Over, by Race/Ethnicity and Sex: Selected Years, 1910 Through 2017," https://bit.ly/2TzkOTS.

22. Brookings Institution, 2012, Michael Greenstone and Adam Looney, "Regardless of the Cost, College Still Matters," https://bit.ly/1kpvZsp.

23. "Graduate Indebtedness: Its Perceived Effects on Behavior and Life Choices: A Literature Review," 2018, Ariane de Gayardon, Claire Callender, K.C. Deane, and Stephen DesJardins, https://bit.ly/2RxhQwr; A. Minicozzi, Economics of Education Review, 2005, "The Short Term Effect of Educational Debt on Job Decisions," https://bit. ly/36yBE6C; J. Rothstein and C.E. Rouse, Journal of Public Economics 95 (2011), "Constrained After College: Student Loans and Early-Career Occupational Choices," 149-63.

24. TICAS, 2018, "The Self-Defeating Consequences of Student Loan Default," https://bit.ly/2PThD2A.

25. TICAS, 2019, "Quick Facts About Student Debt," https:// bit.ly/2GuW9qy.

26. Brookings Institution, 2018, Judith Scott-Clayton, “The Looming Student Loan Default Crisis Is Worse Than We Thought," https://brook.gs/2EanLBr. 
27. TICAS, 2019, “Quick Facts About Student Debt,” https:// bit.ly/2WqxMQ5; TICAS, 2018 "Students at Greatest Risk of Loan Default," https://bit.ly/2rb8doK; TICAS, 2019, "Casualties of College Debt: What Data Show and Experts Say About Who Defaults and Why," https://bit.ly/2U09cYX.

28. Brookings Institution, 2015, Adam Looney and Constantine Yannelis, "A Crisis in Student Loans? How Changes in the Characteristics of Borrowers and the Institutions They Attended Contributed to Rising Loan Defaults," https://brook.gs/2w7QuAA.

29. Calculations by TICAS on data from the U.S. Department of Education, IPEDS 12-month unduplicated headcount for all students enrolled in schools in the 50 states plus the District of Columbia, and FY 2016 three-year cohort default rates (CDRs).

30. NPR, 2019, Cory Turner, "Betsy DeVos Overruled Education Dept. Findings on Defrauded Student Borrowers," https://n.pr/36FNEUg.

31. Bennet for America, https://bit.ly/30WYfZq, accessed January 27, 2020; Biden for President, https://bit.ly/37yJiPP, accessed January 27, 2020; Amy Klobuchar, "Senator Klobuchar's 'Many Paths to Success' Post-Secondary Education Plan," 2019, https://bit.ly/2t68LBk; Deval for All, "People Over Profits Economic Agenda," https://bit. ly/38IkAN3; Tom Steyer, https://bit.ly/2t6USCX.

32. Yang 2020, https://bit.ly/37M5PIV.

33. Weld 2020, https://bit.ly/37HZ7E9.

34. Pete For America, https://bit.ly/2vrw6hC.

35. Warren for 2020, https://bit.ly/2vuIJIM.

36. Bernie 2020, https://bit.ly/2U3110f; Tulsi Now, https:// bit.ly/2GubJCI. (Note that the Gabbard campaign website refers to Sen. Sanders' 2017 legislation that would make college free for students with family incomes up to $\$ 125,000$. However, she is also a cosponsor of Sen. Sanders' 2019 bill, which lacks income limits.)

37. Amy Klobuchar, 2019, "Senator Klobuchar's 'Many Paths to Success' Post-Secondary Education Plan," https://bit. ly/2t68LBk; Chronicle of Higher Education, 2020, Jonathan Custodio, "Free College, Student-Debt Forgiveness, and Pell Grant Expansion Dominate Higher-Ed Issues for Top Democratic Candidates," https://bit.ly/2NYiscf.

38. Custodio 2020.

39. Bernie 2020, https://bit.ly/2U3110f.

40. Bennet for America, https://bit.ly/30WYfZq.

41. U.S. Department of Education, 2019, "Fiscal Year 2020 Budget Summary," https://bit.ly/2NYiLUr.

42. Bernie 2020, https://bit.ly/2U3110f.
43. Warren for 2020, https://bit.ly/37yzuoY.

44. Bennet for America, https://bit.ly/30WYfZq; Biden for President, https://bit.ly/37yJiPP; Weld 2020, https://bit. ly/37HZ7E9.

45. Tom Steyer 2020, https://bit.ly/2RSlb8d.

46. Amy Klobuchar, 2019, "Senator Klobuchar's 'Many Paths to Success' Post-Secondary Education Plan,” https://bit. ly/2t68LBk.

47. Delaney for President 2020, "Education," https://bit. ly/2U1JiUM; Tulsi Now, https://bit.ly/2GubJCI; Yang 2020, https://bit.ly/2U0qg0R.

48. Wall Street Journal, 2019, Josh Mitchell and Andrew Restuccia, "Trump Administration Weighs Plans to Reduce Student Debt," https://on.wsj.com/30YHk8O.

49. Pete For America, https://bit.ly/30VON8S; Deval for All, "People Over Profits Economic Agenda," https://bit. ly/38IkAN3.

50. Yang 2020, https://bit.ly/2U0qg0R.

51. White House Office of Management and Budget, 2019, "A Budget for a Better America: Promises Kept, Taxpayers First, Major Savings and Reform," https://bit.ly/38GZ0Zo.

52 Bennet for America, https://bit.ly/30WYfZq.

53. Biden for President, https://bit.ly/37yJiPP.

54. Yang 2020, https://bit.ly/2U0qg0R.

55. Student Loan Hero, 2020, Rebecca Safier, "Presidential Candidates on Student Loans: The Complete 2020 Guide," https://bit.ly/2U2gATI.

56. Amy Klobuchar, 2019, “Senator Klobuchar's 'Many Paths to Success' Post-Secondary Education Plan,” https://bit. ly/2t68LBk.

57. Mitchell and Restuccia 2019.

58. Weld 2020, https://bit.ly/37HZ7E9.

59. Biden for President, https://bit.ly/37yJiPP; Pete For America, https://bit.ly/30VON8S; Amy Klobuchar, 2019,

"Senator Klobuchar's 'Many Paths to Success' PostSecondary Education Plan," https://bit.ly/2t68LBk.

60. Bennet for America, https://bit.ly/30WYfZq; Yang 2020, https://bit.ly/2U0qg0R.

61. Pete For America, https://bit.ly/30VON8S.

62. Biden for President, https://bit.ly/37yJiPP.

63. Deval for All, "People Over Profits Economic Agenda," https://bit.ly/38IkAN3.

64. Bernie 2020, https://bit.ly/2U3110f. 


\section{About the Authors}

James Kvaal is the president, and Jessica Thompson is the director of policy and planning, at the Institute for College Access \& Success, a trusted source of research, design, and advocacy for student-centered public policies that promote affordability, accountability, and equity in higher education. Kvaal previously served as the policy director on the 2012 Obama and 2008 Edwards presidential campaigns. Before joining TICAS, Jessica spent six years as a higher education policy analyst for the University of Washington. To learn more about TICAS, visit ticas.org or follow TICAS on Twitter at @TICAS_org.

\section{Acknowledgments}

The authors thank Lindsay Ahlman, Oliver Schak, and Madison Weiss of TICAS, as well as the faculty and staff of the University of New Hampshire Carsey School of Public Policy, for research and editorial assistance. TICAS’ work is made possible by its foundation partners and individual donors. The views expressed in this paper are solely those of the authors and do not necessarily reflect the views of its funders. This report can be reproduced, with attribution, within the terms of this Creative Commons license: creativecommons.org/licenses/by-nc-nd/3.0/.

The Carsey School of Public Policy at the University of New Hampshire is a nationally acclaimed resource for research, leadership development, and engaged scholarship relevant to public policy. We address the most pressing challenges of the twenty-first century, striving for innovative, responsive, and equitable solutions at all levels of government and in the for-profit and nonprofit sectors.

Huddleston Hall • 73 Main Street • Durham, NH 03824

(603) 862-2821

TTY UsERS: DIAL 7-1-1 OR 1-800-735-2964 (RELAY N.H.)

carsey.unh.edu 